Federal Reserve Bank of Minneapolis
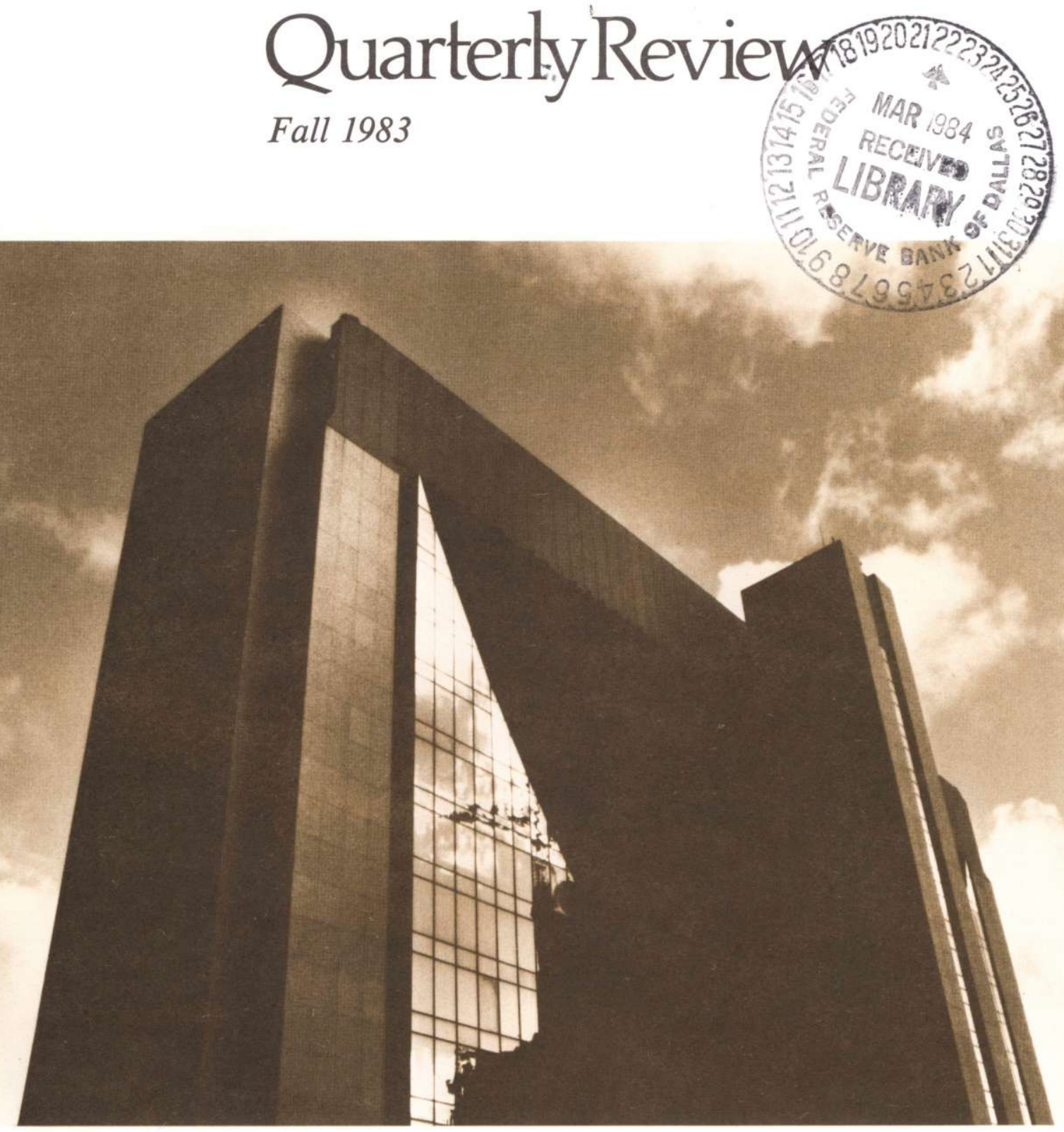
Federal Reserve Bank of Minneapolis

\section{Quarterly Review vol. 7, No.4 ISSN 0271-5287}

This publication primarily presents economic research aimed at improving policymaking by the Federal Reserve System and other governmental authorities.

Produced in the Research Department. Edited by Richard M. Todd and Inga Velde.

Graphic design by Phil Swenson and typesetting by Barbara Cahlander and Terri Desormey, Graphic Services Department.

Address requests for additional copies to the Research Department,

Federal Reserve Bank, Minneapolis, Minnesota 55480.

Articles may be reprinted if the source is credited and the Research Department is provided with copies of reprints.

The views expressed herein are those of the authors and not necessarily those of the Federal Reserve Bank of Minneapolis or the Federal Reserve System. 


\title{
Speculations About the Speculation Against the Hong Kong Dollar
}

\author{
David T. Beers, Thomas J. Sargent, and Neil Wallace*
}

In this paper, we attempt to explain the Hong Kong dollar's recent substantial depreciation, or its loss in value in terms of foreign exchange. This task is a challenge mainly because of the unusual monetary policy recently espoused by the government of Hong Kong. From 1974 until October 1983, the officially professed policy allowed both the quantity and the exchange value of Hong Kong currency to be determined by market forces (or to float). The subject is also interesting because current events in Hong Kong are so much affected by expectations, expectations about what will happen after 1997, the year that Britain's lease on most of the colony's territory expires.

The recent depreciation was indeed substantial. Between mid-1980 and October 1983, when the government announced a new policy, the U.S. dollar value of the Hong Kong dollar fell about 33 percent. During that period, there also occurred substantial declines (even in terms of local currency) in the value of assets located in Hong Kong-Hong Kong real estate and common stock in Hong Kong companies. All of these declines coincided with a generally unfavorable reassessment of the prospects for maintaining the political status quo beyond 1997.

The unfavorable reassessment easily accounts for a decline in real estate and stock market values. Prospective events after 1997 can reasonably be expected to reduce the stream of returns flowing to the owners of real estate and shares in Hong Kong so that their value now would fall. The fall in the Hong Kong dollar has also been widely attributed to unfavorable speculation about 1997 , apparently on the basis of a vague notion that the Hong Kong dollar is somehow a claim against the wealth of the current residents of Hong Kong. Closer scrutiny shows that movements in the value of the Hong Kong dollar are not directly linked with speculation about 1997 . This is because the events of 1997 do not adversely affect interest-bearing foreign assets held as backing for the currency by the Hong Kong government. Thus, distinct lines of reasoning seem to be needed to account for the fall of Hong Kong real estate and stock prices, on the one hand, and the fall of the foreign exchange value of the Hong Kong dollar, on the other.

We explain the depreciation of the Hong Kong dollar as the result of a chain of influences involving the Hong Kong government and speculation about the events of 1997. The existence of this chain of influences is supported by indirect evidence that the Hong Kong government actually departed from its pre-October 1983 official float policy. In particular, we interpret the depreciation of the Hong Kong dollar as having been welcomed and supported by the government in order to help private financial intermediaries in Hong Kong face the substantial declines in the real value of Hong Kong real estate and other real assets.

Our case for this interpretation rests heavily on how we think the Hong Kong monetary system would have functioned if the government had actually adhered to its float policy. We argue that under that policy market fundamentals alone could not have determined an equilibrium exchange rate for the Hong Kong dollar and, in particular, did not propel that rate downward. Our circumstantial evidence supporting the case that the government departed from its official policy in order to promote the depreciation of the Hong Kong dollar is

*Sargent and Wallace are advisers to the Research Department of the Federal Reserve Bank of Minneapolis and professors of economics at the University of Minnesota. Beers is an assistant vice president at Bankers Trust Company who independently collaborated with Sargent and Wallace on this paper. 
supported by an analysis of who stood to gain and who stood to lose from such a depreciation. ${ }^{1}$

\section{A Look at Hong Kong's Monetary System}

Monetary and fiscal affairs in Hong Kong are now managed by a single institution, known as the Exchange Fund. (Though originally just Hong Kong's monetary institution, it took on most of the Treasury's functions in 1977.)

The types of items on the Exchange Fund's balance sheet, divided into parts attributable to the monetary branch and the fiscal branch, are shown in Figure 1. The certificates of indebtedness are non-interest-bearing instruments held by private banks as backing for currency. The debt certificates are an internal bookkeeping device between the monetary and fiscal branches of the Exchange Fund, which completely net out in the consolidated balance sheet. They seem to be a device for crediting the revenues accumulated from currency issue (the seignorage) to the fiscal branch.

The Exchange Fund issues all of Hong Kong's coins, but two large private banks issue most of the paper currency, known as the Hong Kong dollar (HK\$). These banks are the Hongkong and Shanghai Bank, which issues from 80 to 90 percent of the paper currency, and the Chartered Bank, which issues most of the rest.

These private banks issue the currency entirely at their own discretion, but they do not profit greatly from this privilege. Since the banks' names appear prominently on

Figure 1

The Exchange Fund's Balance Sheet

\begin{tabular}{lll} 
Branch & Assets & Liabilities \\
\hline Monetary & Foreign exchange & $\begin{array}{l}\text { Certificates of } \\
\text { indebtedness }\end{array}$ \\
& $\begin{array}{l}\text { Hong Kong bank } \\
\text { deposits denominated } \\
\text { in Hong Kong dollars }\end{array}$ & Debtcertificates \\
\hline
\end{tabular}

Fiscal Foreign exchange Net worth

Hong Kong bank deposits denominated

in Hong Kong dollars

Debt certificates the notes, they get some prestige and free advertising from the privilege. However, as already noted, the government collects all of the seignorage. It does this by requiring the banks to hold, behind all currency issues, 100 percent reserves of the non-interest-bearing certificates of indebtedness mentioned above as liabilities of the Exchange Fund. ${ }^{2}$ The banks must buy these certificates of indebtedness from the Exchange Fund, which holds as assets behind these certificates a portfolio of interestbearing assets denominated in foreign currencies and interest-bearing deposits in accounts in Hong Kong banks. These assets can thus be thought of as ultimately backing the Hong Kong dollar. The regulation governing certificates of indebtedness states that they are redeemable at the option of the Financial Secretary.

The asset effects of currency issues on the Exchange Fund and the banks are illustrated in Figure 2.

Although only two banks issue notes, there is relatively free entry into other aspects of banking in Hong Kong. Furthermore, there are no reserve requirements against deposits and no government-supplied deposit insurance. There is a cartel, the Hong Kong Association of Banks, which sets interest rates.

\section{The Official Float Policy}

The system just described contains vestiges of Hong Kong's pre-1972 system, which was a British Currency Board System. In that system, the Exchange Fund pegged the Hong Kong dollar to the British pound. Behind certificates of indebtedness the Exchange Fund held 100 percent reserves in interest-bearing British pound instruments. After 1972, for about two years, the Hong Kong dollar was pegged to the U.S. dollar. Thereafter (until October 1983) it was allowed to float. During the float period, the Exchange Fund held a portfolio of interestbearing instruments denominated in a variety of foreign currencies and of interest-bearing deposits in Hong Kong banks. According to the official policy, the Exchange Fund passively supplied any amount of certificates of indebtedness that the private banks requested in exchange for foreign currencies at market rates of exchange. In effect, then, the Exchange Fund was willing to buy and

\footnotetext{
1 Except for minor editorial changes, most of this paper was written during the summer of 1983. The last section, an epilogue, was written after October 15, 1983, when the Hong Kong authorities announced and implemented a shift to a policy of pegging the value of the Hong Kong dollar to that of the U.S. dollar.

2The government compensates the banks for the cost of issuing and maintaining the stock of currency.
} 
Figure 2

Balance Sheet Effects of Issuing HK\$ 100

\begin{tabular}{|c|c|c|c|c|}
\hline & Assets & & Liabilities & \\
\hline \multirow[t]{2}{*}{$\begin{array}{l}\text { Exchange } \\
\text { Fund }\end{array}$} & Foreign exchange & 85 & $\begin{array}{l}\text { Certificates of } \\
\text { indebtedness }\end{array}$ & 100 \\
\hline & $\begin{array}{l}\text { Hong Kong bank } \\
\text { deposits denominated } \\
\text { in Hong Kong dollars }\end{array}$ & 15 & & \\
\hline $\begin{array}{l}\text { Private } \\
\text { Hong Kong } \\
\text { Banks }\end{array}$ & $\begin{array}{l}\text { Certificates of } \\
\text { indebtedness }\end{array}$ & 100 & $\begin{array}{l}\text { Hong Kong } \\
\text { dollar notes }\end{array}$ & 100 \\
\hline
\end{tabular}

sell Hong Kong dollars for foreign currencies at market rates of exchange.

During the float period, the Exchange Fund mostly kept secret its portfolio composition and its strategy for shifting the composition of the portfolio between foreign currencies and domestic deposits. (The exception is that the amount held in British pound sterling was revealed.) However, the guiding principle of the Exchange Fund's open market strategy seems to have been to hold all or most of its portfolio in foreign currencies. ${ }^{3}$ When the Hong Kong dollar was experiencing temporary weakness, the Exchange Fund might move temporarily into deposits denominated in Hong Kong dollars. Such moves were exceptional and temporary, though. The Exchange Fund professed no intention and acknowledged no ability to influence the basic direction of exchange rates. According to government officials, the exchange rate was determined by fundamental market forces which the Exchange Fund should not, and could not, oppose for long.

\section{An Indeterminate Exchange Rate?}

We strongly suspect that the Hong Kong government did not actually follow its official float policy. A major reason for this suspicion is that, if the policy had been followed, then the exchange rate for the Hong Kong dollar would have been indeterminate. By indeterminate, we mean that there would have been a wide range of values of foreign exchange rates for the Hong Kong dollar that would have cleared markets. This indeterminacy is a consequence of the lack of any anchor in a system in which both the exchange rate and the quantity of Hong Kong dollars float. It results under any theory of the demand for Hong Kong dollars. The indeterminacy is a product of the responses required of the Exchange Fund under the official policy.

To establish that result, let's first examine the options available to the Hong Kong government if it were to have pegged the exchange rate for its currency to one or several foreign currencies. A government doing that simply announces that it is willing to buy and sell unlimited amounts of its currency at the chosen exchange rate. Then it must be prepared to cope with a run on its currency, or an attempt by holders of the domestic currency to convert their holdings into foreign currency. The government need not be concerned about high demands for its own currency, since it can always provide more if needed. This asymmetry produces a range of values at which it is feasible to peg the exchange rate.

To simplify the exposition, suppose that there is only one foreign currency and that at some time a monetary authority has a balance sheet consisting of $f$ units of foreign currency which it possesses as assets and $h$ units of its own (home) currency outstanding which are its liabilities. Starting in this situation, it is feasible for the authority to fix the exchange rate, the value of its own currency in terms of foreign currency, at any value between zero and the ratio $f / h$. That is because, with the

\footnotetext{
${ }^{3}$ Here and elsewhere in this paper, our descriptions of the Hong Kong government's strategy rely heavily on Sargent's discussions with various Hong Kong economists in June 1983.
} 
exchange rate in this range, the foreign exchange value of its $h$ units of home currency remains less than or equal to $f$ since $(h)(f / h)=f]$. In other words, with the rate in this range, no exchange that the authority could be called on to make would more than exhaust its holdings of foreign currency. ${ }^{4}$ (Notice, by the way, that the net worth of the monetary authority [assets less liabilities] varies inversely with the exchange rate, being equal to $f$ when the exchange rate is zero $[f-(h)(0)=f]$ and being equal to zero when the exchange rate is $f / h[f-(h)(f / h)=0]$.)

Evidently, any such fixed rate policy is effective in the sense that the market rate must be the fixed rate. Under the fixed rate policy, the monetary authority would supply the market with any amount of home currency that is demanded at the fixed rate; in other words, at that rate, supply would be perfectly elastic, as shown in Figure 3 . Regardless of the demand for home currency, then, the exchange rate would be the one announced.

Now consider matters under a strict version of Hong Kong's official float policy. Suppose again that the authority starts out holding $f$ units of foreign currency with $h$ units of home currency outstanding. The monetary authority's policy is now to buy and sell any amount of its currency at the exchange rate that the market determines. However, what rate would the market determine? Evidently, under this policy, it could be any rate between zero and $f / h$.

To establish that any such rate could be an equilibrium, we only need to verify that the home currency's supply and demand would be equal at that rate. Consider any particular rate in the interval $[0, f / h]$. Under the float policy, supply at that rate would look just like the perfectly elastic supply curve in Figure 3 because, according to the policy, the authority is willing to buy and sell unlimited amounts at the market rate. At the particular rate, then, regardless of the nature of the demand for home currency, demand would be satisfied. Therefore, the posited rateany rate between zero and $f / h$ - would be an equilibrium, or ruling, exchange rate under the official policy.

To demonstrate in this way that under Hong Kong's official float policy the exchange rate had to be indeterminate cannot be the end of things. For somehow the exchange rate was being determined. Therefore, our analysis is, at best, incomplete. In principle, our analysis could be regarded as defective either because we have mischaracterized how things are supposed to have worked under the official policy or else because the Exchange Fund actually pursued a policy different from
Figure 3

\section{The Supply of Hong Kong Currency Under a Fixed or a Floating Rate Policy}

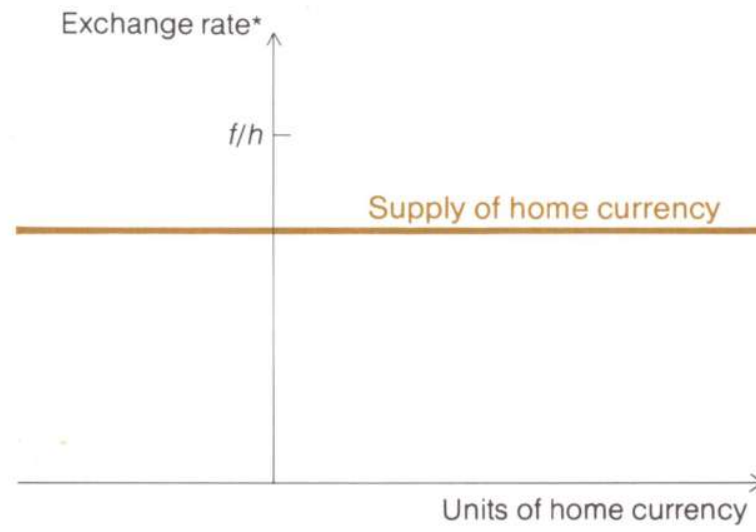

*Units of foreign currency per unit of home currency

the officially professed one. We favor the latter possibility.

We think that the Hong Kong dollar's exchange rate was determined throughout the float period by a series of discreet deviations from the official policy. In practice, the policy is likely to have more closely resembled a fixed rate policy than a strict version of the official policy. In our view, the observed exchange rate was determined by signals given by the Exchange Fund, signals which in effect revealed the exchange rate at which the authority was willing to buy and sell Hong Kong dollars. This was feasible since the Exchange Fund was able to supply unlimited quantities of Hong Kong dollars and since it was continually engaging in transactions with the dealers who announced exchange rates.

\footnotetext{
4 In this pure system, the monetary authority can be regarded as acting as a warehouse for foreign currency, always having at least enough foreign-denominated assets to convert its total outstanding stock of notes. In practice, however, many countries' monetary authorities have managed to peg a rate of exchange of domestic currency for foreign currency while holding foreign exchange reserves that are smaller in value than the stock of outstanding domestic notes. Such a system can be administered if the monetary authority has a commitment from the fiscal authority to run prospective government surpluses sufficient to cover the obligations of the monetary authority in the event of a run. We assume that the Hong Kong system is a pure one, which is to say that the monetary branch of the Hong Kong Exchange Fund operates independently of the fiscal branch and cannot expect future government surpluses or deficits either to augment or to impair the funds available to back the currency.
} 


\section{A Timely Depreciation}

We have no direct evidence that the Exchange Fund ever actually deviated from its official float policy. Our evidence is circumstantial and consists partly of the fact that in practice the exchange rate was somehow tied down even though, under the official policy, it should not have been. Our view is also based on the fact that the recent depreciation in the Hong Kong dollar was quite timely for the Hong Kong government. It came, that is, just when the government would have welcomed it.

Seeing why that is so requires a look at who gains and who loses from the depreciation of this currency. Changes in the exchange rate of the Hong Kong dollar affect the distribution of wealth among issuers and holders of Hong Kong dollar-denominated liabilities. As mentioned above, since the Exchange Fund's portfolio consists primarily of assets denominated in foreign currency while its liabilities are in Hong Kong dollars, its net worth varies inversely with the exchange value of the Hong Kong dollar (the lower the exchange rate, the greater the government's net worth). Offsetting this, in terms of a consolidated balance sheet, everyone else has a net worth that varies directly with the exchange value of the Hong Kong dollar. However, the effects on any particular asset holder depend on the holder's portfolio composition, namely, on the extent to which the holder is unhedged (exposed to risk) with respect to the exchange rate and the direction in which the holder is unhedged. It is primarily in terms related to such effects that we will explain why the authority might have welcomed a depreciation of the Hong Kong dollar.

We will do this by examining the balance sheet of a hypothetical Hong Kong financial firm as it experiences what some real Hong Kong firms may actually have experienced: first a substantial decline in real asset prices and then that decline joined by a substantial decline in the value of the Hong Kong dollar. Our financial firm has some assets in the form of loans, denominated in Hong Kong dollars, which have as collateral real Hong Kong assets and some liabilities, denominated in Hong Kong dollars, in the form of deposits. We will assume, as seems plausible, that the value of the real assets in terms of foreign currency is determined in a world capital market. That is, their value measured in terms of foreign currencies does not depend on the exchange value of the Hong Kong dollar.

Our hypothetical financial institution begins with the balance sheet in the first column of Figure 4 . We measure all entries in foreign currency so that entries denominated in Hong Kong dollars will vary with the exchange rate but those denominated in foreign currency will not. Note that this institution has initial net worth equal to 10 percent of total assets and that it is unhedged with respect to the exchange rate in only a minor way. That is, an exchange rate depreciation would lower net worth in an amount proportional to the initial net worth denominated in Hong Kong dollars, namely, 10 percent of $x$.

We now describe the effect on net worth of a substantial decline in the value, in terms of foreign currency, of the assets which serve as collateral for the loans denominated in Hong Kong dollars. We will assume for the sake of argument a 50 percent decline in the value of these assets, measured in terms of foreign currency, and we will assume that initially the value of the assets was equal to $4 / 3$ of the loans. (Put another way, the loans were equal to 75 percent of the value of the collateral.) In describing the firm's portfolio after the decline, we take the value of such loans to be the value of the collateral if the collateral is worth less than the initial value of the loans.

If the value of the collateral assets falls 50 percent and the exchange rate does not change, then these assumptions imply that loans backed by Hong Kong dollars are defaulted on and the firm's balance sheet changes to that in the second column of Figure 4. A comparison of this column and the first shows that, because of the asset price decline, net worth declines. In fact, it becomes negative, implying bankruptcy, if $x$ is sufficiently larger than $y$.

If the value of the Hong Kong dollar falls at the same time as asset prices, however, the result is not as bad for the financial firm. Suppose that, along with the 50 percent decline in the value of real Hong Kong assets in terms of foreign currency, there occurs a decline of $1 / 3$ in the exchange value of the Hong Kong dollar. (It takes $1 \frac{1}{2}$ times as many Hong Kong dollars to buy one unit of foreign currency as originally.) Then, per Hong Kong dollar of loans originally granted, there is collateral worth $(4 / 3)(1 / 2)(3 / 2)$, or one Hong Kong dollar. Thus, there need be no default on the loans. As the new balance sheet, the last column of Figure 4, indicates, the firm's net worth still declines somewhat from its initial value, but not as much as with just a decline in real asset values. When a depreciation accompanies the asset price decline, therefore, the firm can stay in business.

Individual depositors of the financial firm, of course, would not prefer this situation to the last, for a deprecia- 
Figure 4

How an Exchange Rate Depreciation Can Help a Financial Firm

(Balance Sheet Items Measured in Units of Foreign Currency)

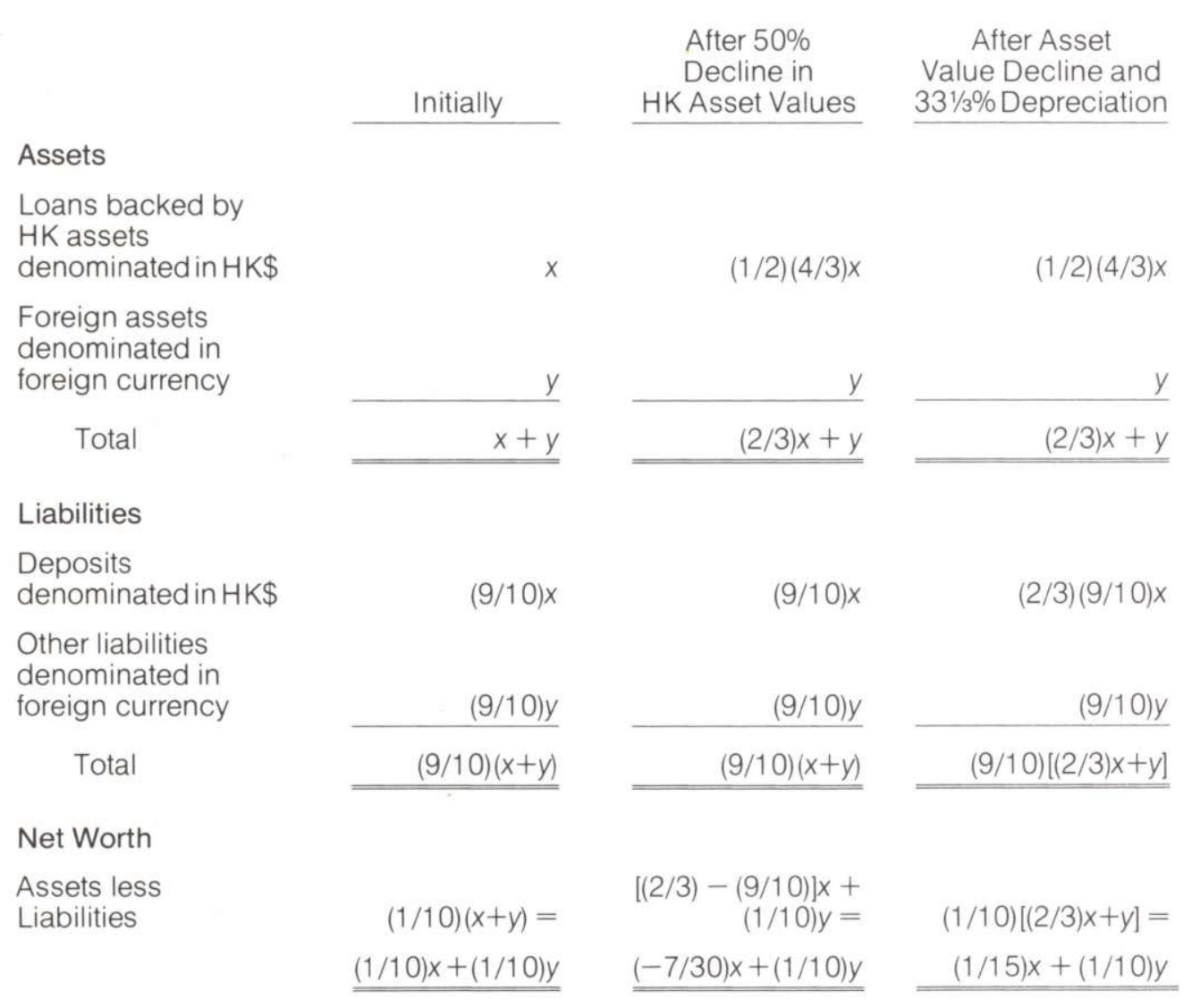

tion reduces the value of their deposits. At the same time, the value of assets in terms of foreign currency is the same whether or not a depreciation occurs. This is true in general. The extent of a depreciation of the Hong Kong dollar determines how the value of total assets is divided among categories of liabilities: the greater the depreciation of the Hong Kong dollar, the smaller the share that goes to deposits denominated in Hong Kong dollars.

Over the last two years, many Hong Kong financial institutions seem to have been in positions like the one depicted here. If they were, then the Exchange Fund could easily have viewed a depreciation of the Hong Kong dollar as a way to avoid the major disruption to the economy that numerous financial firm bankruptcies would cause. A depreciation could smooth the Hong Kong economy's adjustment to lower real property values in terms of foreign currency. The adjustment would be smoother not because financial firms' capital losses 
would be averted, but because they would be allocated partly to depositors, thereby helping to preserve existing financial institutions.

\section{Hong Kong's Other Options}

With the exchange rate indeterminate under the official float policy, it is not surprising that the Hong Kong government should have departed from that policy in practice and reverted to an unofficial policy of pegging the exchange rate. It did, however, have other alternatives.

One feasible alternative is to make its unofficial policy official: to adopt a fixed rate policy in which the Exchange Fund acts as a warehouse for foreign exchange. Then, if government budgets are balanced or in surplus (in a present value sense), it could not only peg but gradually appreciate the Hong Kong dollar. Appreciation could be engineered as a way of paying out all or part of the interest that is earned on the foreign securities that the Exchange Fund holds as reserves. (Singapore evidently manages its currency this way.) Such a policy would be feasible regardless of the fate of the wealth of Hong Kong, as determined by news about 1997 or other factors, as long as the government balanced its budget so that the portfolio available to back the Hong Kong dollar remained intact. ${ }^{5}$

Another alternative that has been suggested is for the Hong Kong government to fix the quantity rather than the exchange rate of Hong Kong dollars and allow the exchange rate to float. (See the article Hong Kong's financial crisis, 1982). However, this proposal is not complete without specific rules governing the asset side of the monetary authority's balance sheet. Whether the proposal would work depends on whether the foreign exchange backing of the currency stock is to be eliminated or maintained.

In one version of this proposal, fixing the quantity of Hong Kong dollars is viewed as a substitute for maintaining backing. Advocates of a fiat money (or unbacked paper money) regime seem to have this view. They see the ability to dispense with backing as a one-time dividend for the monetary authority to spend. The size of this dividend is sometimes said to be a measure of the inefficiency of a backed system compared to a fiat system.

This sort of fiat system would probably not work in Hong Kong. For a fixed-quantity, no-backing regime to determine the exchange rate, there must be a stable demand function for unbacked Hong Kong dollars, in other words, a preference among Hong Kong residents for Hong Kong dollars over other currencies. However, it is questionable that such a preference could exist for a fiat currency issued by the government of an economy as open to trade and capital transactions as is Hong Kong's economy. Foreign currencies circulate in Hong Kong now, and international transactions are not restricted. This suggests that extreme currency substitution potentially prevails in Hong Kong. If it does, then the exchange rate would not be determinate under a regime of a fixed quantity of unbacked Hong Kong dollars (Kareken and Wallace 1981).

The other version of the proposal to fix the quantity of Hong Kong dollars would work, but it doesn't appear to be optimal. In this version, while the quantity of dollars is fixed, its backing is maintained, thus preventing Hong Kong dollars from becoming worthless. However, then there is no reason to fix the quantity. Indeed, when backing of the currency is maintained, it is desirable to allow the demand for Hong Kong dollars to determine their quantity for the same reason that it is desirable to let demand determine the quantities of other kinds of intermediary liabilities (Sargent and Wallace 1982).

\section{Epilogue}

On October 15, 1983, the government abandoned the official float policy and announced a policy of pegging the Hong Kong dollar at 7.80 Hong Kong dollars per U.S. dollar. Short-term interest rates denominated in Hong Kong dollars reacted by climbing sharply, to as high as 40 percent per annum for overnight money. Such high nominal rates can be interpreted as reflecting the market's expectation that the government would not long maintain the current peg and that it would soon devalue. This widespread public pessimism is likely due to a variety of political forces currently operating in Hong Kong which are likely to affect and restrict the government's actual choices in ways we have so far abstracted from.

We have analyzed the valuation of the Hong Kong currency by viewing the monetary affairs branch of the Exchange Fund as though it were managing a mutual

\footnotetext{
5 This argument rests on the same considerations that led Keynes to write this of France in March 1924 (p. xvii):

It is often argued that the franc cannot fall in value because France is a wealthy, thrifty and industrious country, or because her balance of trade is prima facie satisfactory. This ... springs from confusion as to the causes which ultimately govern the value of money. A very rich country can have a very bad currency, and a very poor country a very good one. The wealth of France and her balance of trade may render it easier for her authorities to pursue a sound monetary policy. But they are not the same thing. The value of a country's monetary unit is not a function of its wealth or even its trade balance.
} 
fund. ${ }^{6}$ Given an initial stock, $f$, of assets that are potentially available to redeem Hong Kong currency in terms of foreign exchange, the managers of the mutual fund face a variety of feasible payout policies. The policy that is adopted determines the net worth left to the managers of the fund. For example, among fixed exchange rate policies, the lower is the value of Hong Kong currency, the higher is the net worth.

The Exchange Fund is likely to be managed by the British government until 1997 and by the Chinese government thereafter. In this situation, the Chinese government cares about how the Exchange Fund is administered before 1997, for this will influence the net worth of the fund at the time that the Chinese take over. To see this, suppose, for example, that the British managers of the Exchange Fund were to peg the Hong Kong dollar at the upper bound of the feasible range which we have delineated, namely, $f / h$. Suppose further that holders of Hong Kong dollars (the fund's shareholders) were uncertain about how the new Chinese managers of the fund would manage it. Inevitably, a run on Hong Kong dollars would occur before 1997, a run which the Exchange Fund could meet by drawing down to zero the foreign exchange backing, $f$. Then, the Hong Kong dollar would simply disappear too as the Exchange Fund paid out the backing to the owners of Hong Kong dollars. A fixed rate policy such as this, that values the Hong Kong dollar at (or near) the upper bound $f / h$, could easily be viewed as unfriendly by the current Chinese government. Concern by the current government of Hong Kong to avoid such unfriendly acts could thus constrain the way the Exchange Fund is now managed.

Additional doubts about the likely management of the Exchange Fund between now and 1997 stem from what threaten to be new and growing departures from Hong Kong's traditionally conservative fiscal policy. These departures are partly induced by the fall in value of land and other assets in Hong Kong, the sale and taxing of which the government depends on for revenues.

During the 1970s, the Hong Kong government had budget surpluses totaling 8.6 billion Hong Kong dollars (usually expressed $H K \$ 8.6$ billion). Government investment was financed largely by current revenues and the proceeds of public land sales. As a result, even now Hong Kong's public sector has large net claims on the domestic banking system and on the rest of the world. However, recent declines in government revenues have outpaced attempts to curb public expenditures, with the result that, in 1982-83 and 1983-84, the Hong Kong government had budget deficits for the first time in nearly a decade. These deficits are estimated at HK\$ 3.9 billion and HK\$ 3.2 billion, respectively.

By themselves, two consecutive annual deficits of such magnitude do not threaten responsible management of the Exchange Fund, because the government has accumulated substantial fiscal reserves. At the start of the 198384 financial year, fiscal reserves amounted to HK\$ 18.7 billion, of which HK\$ 11.5 billion constituted free reserves, that is, reserves left after $\mathrm{HK} \$ 7.2$ billion were allocated to cover possible losses on capital projects. Deficits of the current magnitude would not wipe out these free reserves for about three years.

However, continued deficits - and devaluations - may be seen as the only politically feasible ways for the British government to deal with the government's capital losses resulting from the 1997 change in management. The 1997 situation creates special problems with regard to the pricing of services of long-lived, publicly owned capitallike the roads, the subway system, and the public housing. After 1997, the public capital of Hong Kong is likely to belong to the government of China, so that the tail of the stream of taxes and tolls from long-lived capital currently in place or under construction may not be available as backing for debt of the current government. To deal with this situation, the current government could increase charges on existing projects so that the revenue stream collected through 1997 would be sufficient to balance the budget in a present value sense, and it could undertake only those new public investment projects that would pay for themselves by 1997. Such policies would be drastic and amount to managing the economy as though it were going to end in 1997, a stance that could be expected to be opposed both by some current residents of Hong Kong

\footnotetext{
6 Consider a mutual fund with $h$ shares outstanding and with initial assets worth $f$ invested in foreign exchange. There are at least two feasible ways that the mutual fund could operate. First, the mutual fund could close, with no new shares to be issued. On the understanding that shareholders are entitled to a pro rata share of the assets, the market could be permitted to determine a price of shares in the mutual fund. Abstracting from fees, the equilibrium price would be $f / h$. Here the mutual fund would be priced as though it were operating a warehouse for foreign securities. Second, the mutual fund could remain open by offering to sell new shares or redeem existing ones at any fixed price between zero and $f / h$. Thus, either the mutual fund could fix its supply of outstanding shares $h$ and allow the market to price them or it could set a share price at which it would be willing to issue new shares and invest the proceeds. However, a policy of offering to sell or redeem new shares at a price to be set by the market, with the proceeds to be invested and available for redeeming shares, would not pin down enough about the mutual fund's policy.
} 
and by the government of China. Such drastic policies could to some extent be avoided by accepting deficits and devaluations.

Finally, one other recent event raises questions about the Hong Kong government's commitment and ability to adhere to its tradition of conservative fiscal policy. As mentioned earlier, there is no government-supplied deposit insurance in Hong Kong. In the past, some banks have failed, but government intervention has been officially limited to a policy of accepting or encouraging the takeover or merger of threatened banks by or with stronger ones. However, on September 28, 1983, the Hong Kong government departed from this long-standing policy and took over the Hang Lung Bank. The Financial Secretary, Sir John Bremridge, explained this action by saying that the Hang Lung Bank's failure and the resulting losses to depositors were unacceptable to the government.

This departure from long-standing policy can be viewed as a threat to fiscal conservatism and a threat of further devaluations because it represents a major change in the categories of public and private liabilities that are potentially claims against the monetary and fiscal reserves of the government. Under the long-standing policy, only Hong Kong currency was a claim against the government's monetary reserves, while bank deposits represented(risky) claims backed by the (risky) loans and investments of the banks. If the government has instituted a new policy of protecting depositors against potential losses, the stream of implicit government obligations has increased substantially. Without tax increases, these extra obligations threaten to impair the funds available for backing the Hong Kong currency. While it might be desirable for other reasons, therefore, the takeover of the Hang Lung Bank is a signal that market participants could readily interpret as portending a weak Hong Kong dollar.

\section{References}

Hong Kong's financial crisis: History, analysis, prescription. 1982. Asian Monetary Monitor 6 (November-December): 2-69.

Kareken, John, and Wallace, Neil. 1981. On the indeterminancy of equilibrium exchange rates. Quarterly Journal of Economics 96 (May): 207-22.

Keynes, J. M. 1924. Preface to the French edition. In A tract on monetary reform. Reprint 1971. In vol. 4 of The collected writings of John Maynard Keynes, pp. xvi-xxii. London: Macmillan, St. Martin's Press, for the Royal Economic Society.

Sargent, Thomas J., and Wallace, Neil. 1982. The real-bills doctrine versus the quantity theory: A reconsideration. Journal of Political Economy 90 (December): 1212-36. 